\title{
Studi komparasi beberapa metode skrining penilaian status gizi pada pasien dewasa rawat inap rumah sakit
}

The comparative study of different methods nutrition screening assessment for hospitalized patients

\author{
Rizki Andini, Susetyowati, Dian Caturini Sulistyoningrum
}

Departemen Gizi Kesehatan, Fakultas Kedokteran Universitas Gadjah Mada

\begin{abstract}
Background: It is necessary to diagnose level of malnutrition in hospitalized patient to give optimal nutrition support. Many different nutrition screening assessment have been developed. In Indonesia, Simple Nutrition Screening Tool (SNST) that had been used in same hospital and the result was good enough in validity-realibility. Objective: To assessed that SNST were simple and practical nutrition screening tool for detecting level of malnutrition in different type of hospitalized patient. Method: Observational cross-sectional design with total of sampling two hundred and eighty seven adult patients from $2^{\text {nd }}$ and $3^{\text {rd }}$ class of surgical, internal, or neurology ward of RSUD Sleman. Independent variables are SNST, Nutritional Risk Screening (NRS) 2002, Malnutrition Screening Tool (MST), and Malnutrition Universal Screening Tool (MUST). Dependent variables are Subjective Global Assessment (SGA), body mass index (BMI), mid upper arm circumference (MUAC), and hemoglobin (Hb). Receive Operating Curve (ROC) were used for measuring validity of each screening tools. The proportion difference between at-risk group and not at-risk group was assessed by Chi-square test. The mean difference of BMI, MUAC, and Hb between both of group was assessed by independent sample t-test. Results: SNST has highest validity compared to NRS-2002, MST, and MUST with Sensitivity 99,0\%, Specificity 84,5 and Area Under Curve (AUC) 0,917. Based on SNST, the proportion difference of at-risk group and not at-risk group between surgical patients and internal-neurology patients was statistically significant $(p<0,05)$; the proportion difference of at-risk group and not at-risk group between young adult, adult, and elderly patients was statistically significant ( $(<0,05)$; the mean difference of BMI, MUAC, and $\mathrm{Hb}$ between at-risk group and not at-risk group was also statistically significant $(p<0,05)$. Conclusion: All of the nutrition screening tools can be used as predictor of malnutrition in hospitalized patients but, the SNST has the best validity as a nutrition screening to predict malnutrition.
\end{abstract}

KEY WORDS: hospital; malnutrition; nutrition screening tool; validity

\begin{abstract}
ABSTRAK
Latar belakang: Skrining gizi perlu dilakukan untuk mendeteksi risiko malnutrisi pada pasien rawat inap sehingga dukungan gizi dapat diberikan secara optimal. Alat skrining gizi telah banyak dikembangkan salah satunya di Indonesia, Simple Nutrition Screening Tool (SNST) yang berdasarkan studi sebelumnya memiliki validitas dan reliabilitas baik. Tujuan: Mengetahui kemampuan SNST dalam memprediksi malnutrisi bila dibandingkan dengan alat skrining gizi lain pada pasien rawat inap di bangsal yang berbeda. Metode: Penelitian cross-sectional dengan total subjek 287 pasien dewasa yang dirawat inap di kelas II dan III bangsal bedah, penyakit dalam, dan saraf RSUD Sleman. Variabel bebas adalah SNST, Nutritional Risk Screening (NRS) 2002, Malnutrition Screening Tool (MST), dan Malnutrition Universal Screening Tool (MUST). Variabel terikat adalah Subjective Global Assessment (SGA), indeks massa tubuh (IMT), lingkar lengan atas (LLA), dan hemoglobin (Hb). Kurva receive operating curve (ROC) digunakan untuk mengukur validitas masingmasing alat skrining. Perbedaan proporsi malnutrisi antara kelompok berisiko dan tidak berisiko dianalisis menggunakan Chi-Square test sedangkan rerata IMT, LLA, dan Hb menggunakan independent sample t-test. Hasil: SNST memiliki validitas tertinggi dibandingkan NRS 2002, MST, dan MUST dengan nilai sensitivitas 99,0\%; spesifisitas 84,5\%; dan area di bawah kurva ROC 0,917. Perbedaan proporsi malnutrisi berdasarkan SNST antara kelompok berisiko dan tidak berisiko pada ketiga bangsal menunjukkan hasil signifikan $(\mathrm{p}<0,05)$; perbedaan proporsi malnutrisi berdasarkan SNST antara kelompok berisiko dan tidak berisiko pada usia dewasa muda, dewasa, dan lansia menunjukkan hasil signifikan ( $\mathrm{p}<0,05$ ); rerata IMT, LLA, dan $\mathrm{Hb}$ antara kelompok berisiko dan tidak berisiko menunjukkan hasil signifikan $(p<0,05)$. Simpulan: Semua alat skrining gizi dapat digunakan untuk memprediksi malnutrisi pada pasien rawat inap rumah sakit tetapi SNST memiliki nilai validitas terbaik sebagai alat skrining gizi dalam memprediksi malnutrisi.
\end{abstract}

KATA KUNCI: rumah sakit; malnutrisi; skrining gizi; validitas

Korespondensi: Susetyowati, Departemen Gizi Kesehatan, Fakultas Kedokteran Universitas Gadjah Mada, Jl. Farmako, Sekip Utara, Yogyakarta, 55281 Indonesia, e-mail: susetyowati@ugm.ac.id 


\section{PENDAHULUAN}

Tingginya prevalensi malnutrisi pada pasien di rumah sakit masih menjadi perhatian, baik di negara maju maupun negara berkembang. Studi di Amerika Latin menunjukkan prevalensi malnutrisi sebesar 50,2\% dan 11,2\% diantaranya mengalami malnutrisi berat (1), di Jerman prevalensi malnutrisi sebesar 27,4\% (2), di Spanyol prevalensi malnutrisi di rumah sakit sebesar 28,9\% (3). Malnutrisi pada pasien dapat menyebabkan imunitas menurun sehingga masa penyembuhan menjadi lebih lama yang mengakibatkan masa rawat inap dan terapi pun menjadi semakin panjang, biaya pengobatan semakin tinggi, dan secara umum angka morbiditas dan mortalitas juga akan meningkat (4). Kondisi tersebut dapat dicegah apabila deteksi risiko malnutrisi dilakukan lebih dini sejak pasien masuk rumah sakit sehingga implementasi gizi yang optimal dapat diterima pasien lebih awal(5).

Indeks massa tubuh (IMT) dan persentase kehilangan berat badan banyak direkomendasikan sebagai metode untuk mengukur status gizi pada pasien baru masuk di rumah sakit. Namun, kondisi penyakit akut pada pasien tidak selalu memungkinkan untuk dilakukannya pengukuran disebabkan berkurangnya kemampuan pasien untuk berdiri atau bangun dari tempat tidur. Adapun pengukuran lingkar lengan atas (LLA) menjadi salah satu alternatif (6). Selain metode antropometri, deteksi risiko malnutrisi juga dapat dilakukan melalui skrining. Skrining memang bukan dirancang untuk menetapkan status gizi, maupun menetapkan tingkat risiko keparahan malnutrisi pada pasien. Dengan demikian, setiap perangkat skrining gizi harus memiliki sifat mudah dan cepat digunakan dan diinterpretasikan, serta valid dan memiliki daya terima yang baik agar setiap pasien selanjutnya dapat menerima pola asuhan gizi yang sesuai dengan kondisinya masingmasing (7).

Saat ini, sudah banyak perangkat skrining gizi di rumah sakit yang dikembangkan dengan berbagai tujuan, beberapa yang terkenal diantaranya adalah Nutrition Risk Screening 2002 (NRS-2002) yang menjadi rekomendasi European Society for Parenteral and Enteral Nutrition (ESPEN) (8); Malnutrition Screening Tools (MST) yang cepat, mudah, dan digunakan secara luas di Australia dan New Zealand; dan Malnutrition Universal Screening Tools
(MUST) yang dikembangkan oleh British Association of Parenteral and Enteral Nutrition (BAPEN) (9).

Sementara di Indonesia, metode skrining gizi yang dikembangkan di Universitas Gadjah Mada (UGM) yang disebut NST-UGM berisi 6 butir pertanyaan untuk mendeteksi risiko malnutrisi pada pasien dewasa rawat inap dengan sederhana, cepat, dan valid terhadap baku emas Subjective Global Assessment (SGA) (10). NSTUGM yang kemudian diberi nama Simple Nutrition Screening Tool (SNST) ini selain valid, juga memiliki nilai reliabilitas yang baik pada pengukuran skrining yang dilakukan oleh beberapa ahli gizi (kappa $=0,803)$; ahli gizi dan perawat (kappa $=0,653)$; serta ahli gizi dan tenaga pramusaji (kappa $=0,718)(11)$.

Agar menjadi sumber referensi baru untuk menjadi perbandingan dari penelitian sebelumnya, penelitian mengenai SNST kali ini dilakukan di salah satu rumah sakit umum daerah (RSUD) di Yogyakarta karena dianggap memiliki sebaran kasus yang berbeda dengan pasien di rumah sakit umum pusat. Oleh karena itu, lokasi penelitian yang dipilih adalah RSUD Sleman yang merupakan rumah sakit pemerintah rujukan di Kabupaten Sleman dengan tipe RS kelas B non-pendidikan. Tujuan penelitian ini ialah untuk menilai bahwa SNST adalah metode skrining gizi terbaik dibandingkan dengan metode skrining lain seperti NRS-2002, MST, dan MUST terhadap kesesuaiannya dengan baku emas SGA dalam mendeteksi risiko malnutrisi pada pasien dewasa rawat inap di rumah sakit.

\section{BAHAN DAN METODE}

Penelitian merupakan studi observasional dengan rancangan cross-sectional yang dilakukan di RSUD Sleman Yogyakarta pada bulan Maret hingga Juli 2014. Penelitian dilaksanakan setelah mendapat persetujuan dari Komisi Etik Fakultas Kedokteran UGM. Subjek penelitian sebanyak 287 pasien dewasa (di atas 18 tahun) baru yang masuk di bangsal bedah, penyakit dalam, dan saraf kelas perawatan II dan III; dalam kondisi sadar; bersedia mengikuti penelitian; serta dapat diukur berat badan, rentang lengan, dan LLA. Pasien hamil atau postpartum, dengan gangguan jiwa, dan dalam konsidi asites/ oedem tidak diikutsertakan dalam penelitian. Teknik 
pengambilan sampel menggunakan metode non random quota sampling.

Seluruh subjek penelitian diskrining menggunakan kuesioner yang telah dimodifikasi yang merupakan gabungan pertanyaan dalam kuesioner SGA, NRS-2002, MST, MUST, dan SNST. Subjective Global Assessment merupakan kuesioner untuk menilai status gizi, pertanyaan dibagi menjadi 2 kategori, yaitu riwayat medis dan pemeriksaan fisik. Hasil dikelompokkan menjadi 3 kategori, yaitu status gizi baik (SGAA), malnutrisi sedang (SGA B), dan malnutrisi berat (SGA C). Kuesioner ini digunakan sebagai baku emas. Nutrition Risk Screening 2002 terdiri atas skrining awal dan lanjut. Skrining awal terkait IMT, penurunan berat badan (BB), dan asupan makan. Apabila ada 1 jawaban 'ya' maka dilanjutkan ke skrining lanjut yang terdiri atas gangguan status gizi dan status penyakit yang mempengaruhi gizi. Selanjutnya, apabila skor $\geq 3$, maka berisiko malnutrisi. Malnutrition Screening Tool terdiri atas 2 pertanyaan berdasarkan penilaian subjektif, yaitu penurunan BB dan nafsu makan. Pasien berisiko malnutrisi bila skor total $\geq 2$. Malnutrition Universal Screening Tool terdiri atas 4 pertanyaan terkait perubahan $\mathrm{BB}$, asupan makan, $\mathrm{BB}$ saat ini, dan tinggi badan (TB). Pasien dinyatakan berisiko malnutrisi bila total skor $>0$. Simple Nutrition Screening Tool terdiri atas 6 pertanyaan tanpa pengukuran antropometri, diantaranya 'apakah pasien terlihat kurus?'; 'apakah pakaian terasa lebih longgar?'; 'apakah terjadi penurunan BB secara tidak sengaja 3-6 bulan terakhir?'; 'apakah mengalami penurunan asupan makan 1 minggu terakhir?'; 'apakah merasa lemah, loyo, dan tidak bertenaga?'; dan 'apakah ada penyakit yang mempengaruhi asupan makan?'. Risiko malnutrisi dinyatakan bila total skor $>2$ (11).

Pengukuran antropometri dilakukan menggunakan timbangan injak digital, metline, dan pita ukur LLA. Berat badan diukur menggunakan timbangan injak digital dengan akurasi 0,1 kg. Sebelum ditimbang, subjek menggunakan pakaian minimal dan melepaskan asesoris yang digunakan. Subjek naik ke atas timbangan dengan badan tegak, rileks, dan pandangan menghadap lurus ke depan. Sementara tinggi badan diukur menggunakan metline dengan akurasi $0,1 \mathrm{~cm}$. Subjek berdiri tegak menghadap ke arah pengukur dengan kepala bagian belakang, bahu, pantat, betis, dan tungkai menempel di bidang datar (tembok) serta pandangan menghadap lurus ke depan. Indeks massa tubuh kemudian dihitung dengan rumus berat badan $(\mathrm{kg}) /$ tinggi badan ${ }^{2}\left(\mathrm{~m}^{2}\right)$ dan diinterpretasikan (12). Lingkar lengan atas diukur menggunakan pita ukur LLA dengan cara posisi tangan kiri subjek menekuk $90^{\circ}$, kemudian menentukan titik tengah pengukuran dari hasil pengukuran panjang akromion ke olekranon. Dari titik tengah, pita dilingkarkan tegak lurus sumbu tubuh (12). Data kadar hemoglobin $(\mathrm{Hb})$ pasien diperoleh secara observasi dalam rekam medis.

Setelah diperoleh data isian kuesioner skrining, pengukuran antropometri, dan observasi kadar $\mathrm{Hb}$, selanjutnya dilakukan rekapitulasi, koding, dan pengolahan data dengan analisis statistik menggunakan software IBM SPSS Statistics 21. Nilai validitas (sensitivitas dan spesifisitas) masing-masing perangkat skrining diperoleh melalui analisis tabel kontingensi. Receiver Operating Characteristic (ROC) dilakukan untuk mendapatkan nilai Area Under Curve (AUC) dari metode skrining terhadap SGA. Perbedaan proporsi kelompok berisiko dan tidak berisiko pada kelompok umur dan bangsal diketahui melalui uji Chi-square. Perbedaan rerata LLA pada kelompok berisiko dan tidak berisiko diketahui melalui uji independent sample t-test karena data terdistribusi normal, sementara IMT dan kadar $\mathrm{Hb}$ pada kelompok berisiko dan tidak berisiko diketahui melalui uji non-parametrik Mann Whitney $u$-test karena data tidak terdistribusi normal.

\section{HASIL}

\section{Karakteristik subjek penelitian}

Karakteristik subjek penelitian pada Tabel 1 menunjukkan bahwa dari 287 pasien yang menjadi subjek penelitian terdapat $42,2 \%$ yang berjenis kelamin laki-laki dan $57,8 \%$ berjenis kelamin perempuan. Pasien yang menjadi subjek penelitian berasal dari tiga bangsal, yaitu bangsal bedah, penyakit dalam (PD), dan saraf. Terkait ada atau tidaknya tindakan pembedahan yang mampu menyebabkan risiko komplikasi dan infeksi lebih lanjut (13), kelompok perawatan pasien pada penelitian ini kemudian dibagi menjadi dua yaitu bedah dan $\mathrm{PD}+$ saraf. Dengan demikian, pada penelitian ini terdapat sebesar $44,6 \%$ pasien yang berasal dari bangsal bedah dan $55,4 \%$ pasien yang berasal dari bangsal $\mathrm{PD}+$ saraf. 


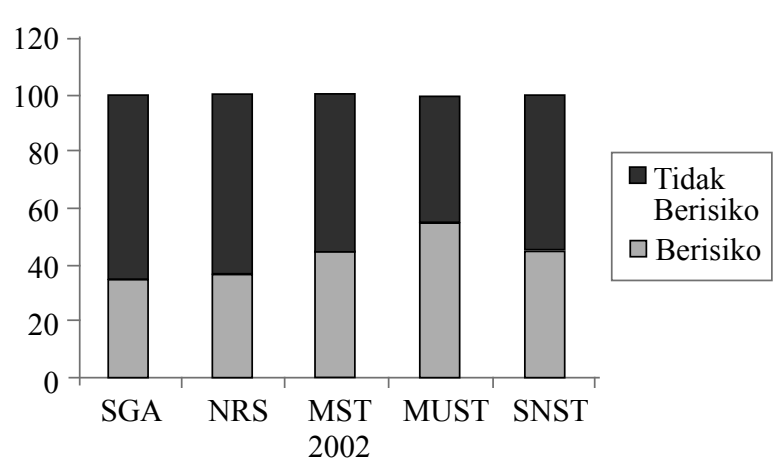

Keterangan: SGA=Subjective Global Assessment; NRS-2002=Nutrition Risk Screening 2002; MST=Malnutrition Screening Tool; MUST=Malnutrition Universal Screening Tool; SNST=Simple Nutrition Screening Tool

Gambar 1. Grafik prevalensi kelompok berisiko dan tidak berisiko berdasarkan SGA, NRS-2002, MST, MUST, dan SNST

Tabel 1. Karakteristik subjek penelitian

\begin{tabular}{lcc}
\hline \multicolumn{1}{c}{ Variabel } & $\mathbf{n}$ & $\mathbf{\%}$ \\
\hline Jenis kelamin & & \\
Laki-laki & 121 & 42,2 \\
$\quad$ Perempuan & 166 & 57,8 \\
Bangsal & & \\
Bedah & 128 & 44,6 \\
PD+saraf & 159 & 55,4 \\
Kelompok umur (tahun) & & \\
Dewasa muda (18-40) & 75 & 26,1 \\
Dewasa tua (40-60) & 131 & 45,6 \\
$\quad$ Usia Lanjut (>60) & 81 & 28,2 \\
Total & 287 & 100,0 \\
\hline
\end{tabular}

Kelompok umur dapat dibagi ke dalam tiga kelompok, yaitu dewasa muda (18-40 tahun), dewasa tua atau disebut juga usia pertengahan (40-60 tahun) dan usia lanjut ( $>60$ tahun) (14). World Health Organisation (WHO) juga membatasi kelompok usia lanjut dimulai pada 60 tahun ke atas. Berdasarkan kelompok umur tersebut, terdapat $26,1 \%$ pasien dewasa muda; $45,6 \%$ pasien dewasa tua; dan 28,2\% pasien usia lanjut.

Berdasarkan Gambar 1, terdapat kelompok pasien berisiko malnutrisi menurut SGA sebanyak 100 orang (34,8\%), NRS-2002 105 orang (36,6\%), MST 129 orang (45,0\%), MUST 157 orang (54,7\%), dan SNST 128 orang $(44,6 \%)$. Sementara kelompok pasien tidak berisiko malnutrisi menurut SGA sebanyak 187 orang (63,2\%), NRS-2002 182 orang (63,4\%), MST 158 orang (55,0\%), MUST 130 orang (45,3\%), dan SNST 159 orang $(55,4 \%)$. Selanjutnya, dapat dilihat perbandingan proporsi kelompok berdasarkan masing-masing metode skrining jika dibandingkan dengan SGA sebagai baku emas melalui analisis tabel kontingensi (Tabel 2)

\section{Perbandingan validitas NRS-2002, MST, MUST, dan SNST terhadap baku emas SGA}

Melalui Tabel 2 dapat diketahui nilai sensitivitas (Se) dan spesifisitas (Sp). NRS-2002 memiliki nilai Se 84\% dan Sp 88,8\%; MST memiliki nilai Se 92\% dan Sp $80,2 \%$; MUST memiliki nilai Se 94\% dan Sp 66,3\%; dan SNST memiliki nilai Se 99\% dan Sp 84,5\%.

Tabel 2. Perbandingan proporsi kelompok risiko berdasarkan masing-masing metode skrining terhadap SGA

\begin{tabular}{|c|c|c|c|c|c|c|}
\hline \multirow{3}{*}{$\begin{array}{l}\text { Metode } \\
\text { skrining }\end{array}$} & \multirow{3}{*}{$\begin{array}{c}\text { Risiko } \\
\text { malnutrisi }\end{array}$} & \multicolumn{4}{|c|}{ SGA $^{1}$} & \multirow{3}{*}{ Kappa } \\
\hline & & \multicolumn{2}{|c|}{ Manutrisi } & \multicolumn{2}{|c|}{ Tidak malnutrisi } & \\
\hline & & $\mathrm{n}$ & $\%$ & $\mathbf{n}$ & $\%$ & \\
\hline \multirow[t]{2}{*}{ NRS-2002 } & Berisiko & 84 & $84,0^{\mathrm{a}}$ & 21 & 11,2 & 0,719 \\
\hline & Tidak berisiko & 16 & 16,0 & 166 & $88,8^{\mathrm{b}}$ & \\
\hline \multirow[t]{2}{*}{$\mathrm{MST}^{3}$} & Berisiko & 92 & $92,0^{\mathrm{a}}$ & 37 & 19,8 & 0,677 \\
\hline & Tidak berisiko & 8 & 8,0 & 150 & $80,2^{b}$ & \\
\hline \multirow[t]{2}{*}{ MUST $^{4}$} & Berisiko & 94 & $94,0^{\mathrm{a}}$ & 63 & 33,7 & 0,532 \\
\hline & Tidak berisiko & 6,0 & 6,0 & 124 & $66,3^{b}$ & \\
\hline \multirow[t]{2}{*}{$\mathrm{SNST}^{5}$} & Berisiko & $99,0^{\mathrm{a}}$ & $99,0^{\mathrm{a}}$ & 29 & 15,5 & 0,784 \\
\hline & Tidak berisiko & 1,0 & 1,0 & 158 & $84,5^{\mathrm{b}}$ & \\
\hline
\end{tabular}

a Sensitivitas; ${ }^{\mathrm{b} S p e s i f i s i t a s ; ~}{ }^{1} \mathrm{SGA}=$ Subjective Global Assessment; ${ }^{2} \mathrm{NRS}-2002=$ Nutrition Risk Screening 2002; ${ }^{3} \mathrm{MST}=$ Malnutrition Screening Tool; ${ }^{4} \mathrm{MUST}=$ Malnutrition Universal Screening Tool; ${ }^{5} \mathrm{SNST}=$ Simple Nutrition Screening Tool 
Tabel 3. Ringkasan ukuran validitas metode skrining

\begin{tabular}{lcccc}
\hline \multicolumn{1}{c}{ Variabel } & Se$^{\mathbf{1}} \mathbf{( \% )}$ & $\mathbf{S p}^{\mathbf{2}} \mathbf{( \% )}$ & $\mathbf{M S S S}^{\mathbf{3}}$ & AUC $^{\mathbf{4}}$ \\
\hline NRS-2002 $^{\mathbf{5}}$ & 84,0 & 88,8 & 172,8 & 0,864 \\
$\mathrm{MST}^{6}$ & 92,0 & 80,2 & 172,2 & 0,861 \\
$\mathrm{MUST}^{7}$ & 94,0 & 66,3 & 160,3 & 0,802 \\
SNST $^{8}$ & 99,0 & 84,5 & 183,5 & 0,917 \\
\hline
\end{tabular}

Analisis menggunakan kurva ROC; ${ }^{1}$ Sensitivitas; ${ }^{2}$ Spesifisitas; ${ }^{3} \mathrm{MSSS}=$ Maximum Sum of Sensitivitas and Specificity; ${ }^{4} \mathrm{AUC}=$ Area Under Curve $;{ }^{5}$ NRS-2002 =Nutrition Risk Screening 2002; ${ }^{6} \mathrm{MST}=$ Malnutrition Screening Tool; ${ }^{7}$ MUST=Malnutrition Universal Screening Tool; ${ }^{8} \mathrm{SNST}=$ Simple Nutrition Screening Tool

Tabel 4. Perbedaan proporsi kelompok pasien berisiko dan tidak berisiko pada masing-masing bangsal perawatan

\begin{tabular}{cccccc}
\hline \multirow{3}{*}{ Bangsal } & \multicolumn{9}{c}{ SNST } & \multirow{2}{*}{$\mathbf{p}^{\mathbf{1}}$} \\
\cline { 2 - 5 } & \multicolumn{2}{c}{ Berisiko } & \multicolumn{2}{c}{ Tidak berisiko } & \multirow{2}{*}{$\mathbf{p}$} \\
\cline { 2 - 5 } & $\mathbf{n}$ & $\mathbf{\%}$ & $\mathbf{n}$ & $\mathbf{\%}$ & \\
\hline Bedah & 24 & 18,8 & 104 & 81,2 & $<0,0001$ \\
PD+saraf & 104 & 65,4 & 55 & 34,6 & 0,0001 \\
\hline
\end{tabular}

${ }^{1}$ analisis menggunakan kurva ROC

a) $\%=\frac{n \text { berisiko pada bangsal " } \mathrm{x} \text { " }}{\mathrm{n} \text { total berisiko dan tidak berisiko pada bangsal " } \mathrm{x}} \times 100 \%$

b) $\%=\frac{n \text { tidak berisiko pada bangsal " } \mathrm{x}^{n}}{\mathrm{n} \text { total berisiko dan tidak berisiko pada bangsal " } \mathrm{x}} \times 100 \%$

Tabel 5. Perbedaan distribusi kelompok pasien berisiko dan tidak berisiko pada masing-masing kelompok umur

\begin{tabular}{|c|c|c|c|c|c|}
\hline \multirow{3}{*}{$\begin{array}{c}\text { Kelompok umur } \\
\text { (tahun) }\end{array}$} & \multicolumn{4}{|c|}{ SNST } & \\
\hline & \multicolumn{2}{|c|}{ Berisiko } & \multicolumn{2}{|c|}{ Tidak berisiko } & \\
\hline & $\mathbf{n}$ & $\%^{\mathrm{a}}$ & $\mathbf{n}$ & $\%^{\mathrm{b}}$ & \\
\hline Dew & 25 & 33,3 & 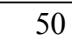 & 66,7 & 0,004 \\
\hline Dewa & 58 & 44,3 & 73 & 55,7 & 0,190 \\
\hline Usia lanjut $(>60)$ & 45 & 55,6 & 36 & 44,4 & 0,317 \\
\hline
\end{tabular}

${ }^{1}$ metode Chi Square

a) $\%=\frac{n \text { berisiko pada bangsal " } \mathrm{X} \text { " }}{\mathrm{n} \text { total berisiko dan tidak berisiko pada bangsal " } \mathrm{X}} \times 100 \%$

$\left.{ }^{b}\right) \%=\frac{n \text { tidak berisiko pada bangsal " } \mathrm{x}}{\mathrm{n} \text { total berisiko dan tidak berisiko pada bangsal " } \mathrm{X}^{n}} \times 100 \%$

SNST memiliki nilai kappa terbaik di antara perangkat skrining lain, yaitu senilai 0,784. Artinya, apabila dibandingkan dengan metode lain, SNST memiliki kesepakatan atau kesesuaian yang paling baik dengan baku emas dalam mengukur risiko malnutrisi.

Setelah diperoleh nilai Se dan Sp, selanjutnya dapat dihitung ukuran validitas lain dalam nilai MSSS yang merupakan penjumlahan dari nilai Se dan Sp itu sendiri. Pada Tabel 3, SNST memiliki nilai MSSS paling tinggi sebesar 183,5 dibandingkan dengan metode skrining
NRS-2002 (172,8); MST (172,2); dan MUST (160,3). Ukuran validitas yang juga dapat diketahui adalah AUC atau luas area di bawah kurva melalui analisis statistik, menggunakan kurva ROC. Luas area bawah kurva dimulai dari yang paling besar adalah $\operatorname{SNST}(0,917)$; NRS-2002 (0,864); MST $(0,861)$; dan $\operatorname{MUST}(0,802)$.

Perbandingan proporsi risiko malnutrisi berdasarkan SNST pada kelompok pasien di masing-masing bangsal perawatan

Pada Tabel 4, proporsi kelompok di bangsal bedah yang berisiko malnutrisi sebanyak $18,8 \%$ berbeda secara bermakna $(\mathrm{p}<0,0001)$ dengan kelompok yang tidak berisiko malnutrisi sebanyak $81,2 \%$, sementara proporsi kelompok di bangsal PD+syaraf yang berisiko malnutrisi sebanyak $65,4 \%$ berbeda secara bermakna $(\mathrm{p}=0,0001)$ dengan kelompok yang tidak berisiko malnutrisi sebanyak $34,6 \%$.

\section{Perbandingan proporsi risiko malnutrisi berdasarkan SNST pada masing-masing kelompok umur pasien}

Berdasarkan Tabel 5, kategori berisiko dan tidak berisiko malnutrisi didasarkan pada skrining menggunakan SNST. Proporsi kelompok dewasa muda yang berisiko malnutrisi sebanyak $33,3 \%$ berbeda secara bermakna $(p=0,004)$ dengan kelompok yang tidak berisiko sebanyak $66,7 \%$; proporsi kelompok dewasa tua yang berisiko malnutrisi sebanyak $44,3 \%$ tidak berbeda secara bermakna $(\mathrm{p}=0,190)$ dengan kelompok yang tidak berisiko sebanyak 55,7\%; lalu proporsi kelompok usia lanjut yang berisiko malnutrisi sebanyak 55,6\% tidak berbeda secara bermakna $(\mathrm{p}=0,317)$ dengan kelompok yang tidak berisiko sebanyak $44,4 \%$.

Perbandingan nilai parameter antropometri IMT, LLA, dan kadar Hb pada kelompok pasien berisiko dan tidak berisiko berdasarkan metode SNST

Tabel 6 merupakan hasil analisis perbandingan nilai parameter IMT, LLA, dan kadar Hb pada masingmasing kategori risiko malnutrisi berdasarkan SNST. Berdasarkan beberapa variabel yang diukur, hanya LLA yang pengukurannya dapat dilakukan terhadap seluruh subjek penelitian, sementara hanya 220 subjek yang memiliki data perhitungan IMT dari pengukuran BB 
Tabel 6. Perbandingan nilai paremeter antropometri IMT, LLA, dan kadar Hb pada kelompok pasien berisiko dan tidak berisiko

\begin{tabular}{lcccc}
\hline \multirow{2}{*}{$\begin{array}{c}\text { Kelompok umur } \\
\text { (tahun) }\end{array}$} & $\mathbf{n}$ & Berisiko & Tidak berisiko & \multirow{2}{*}{ SNST } \\
\cline { 2 - 4 } & 220 & $20,79(18,35-24,24)^{1}$ & $22,74(19,24-26,06)^{1}$ & $0,009^{3}$ \\
\hline IMT $\left(\mathrm{kg} / \mathrm{m}^{2}\right)$ & 287 & $25,28 \pm 4,25^{2}$ & $28,15 \pm 4,92^{2}$ & $<0,000^{4}$ \\
LLA $(\mathrm{cm})$ & 239 & $12,85(10,48-13,85)^{1}$ & $13,20(11,90-14,4)^{1}$ & $0,048^{3}$ \\
Kadar Hb $(\mathrm{g} / \mathrm{dL})$ & &
\end{tabular}

${ }^{1}$ Median (Q1 - Q3); ${ }^{2}$ Rata-rata \pm SD; ${ }^{3}$ Uji Mann-Whitney U-Test; ${ }^{4}$ Uji Independent Sample T-test

dan RL, serta 239 subjek penelitian yang memiliki data pengukuran $\mathrm{Hb}$. Nilai median IMT sebesar $20,79 \mathrm{~kg} / \mathrm{m}^{2}$ pada kelompok berisiko dan $22,74 \mathrm{~kg} / \mathrm{m}^{2}$ pada kelompok tidak berisiko; nilai rata-rata LLA sebesar 25,28 \pm 4,25 $\mathrm{cm}$ pada kelompok berisiko dan 28,15 $\pm 4,92 \mathrm{~cm}$ pada kelompok tidak berisiko; nilai median kadar $\mathrm{Hb}$ sebesar $12,85 \mathrm{~g} / \mathrm{dL}$ pada kelompok berisiko dan 13,20 g/dL pada kelompok tidak berisiko. Hasil analisis menunjukkan adanya perbedaan median IMT $(\mathrm{p}=0,009)$, rerata LLA $(\mathrm{p}<0,0001)$, dan median kadar $\mathrm{Hb}(\mathrm{p}=0,048)$ yang bermakna antara kelompok berisiko dan tidak berisiko.

\section{BAHASAN}

Berdasarkan hasil analisis, semua alat skrining yang digunakan memiliki nilai validitas yang baik, tetapi nilai validitas SNST adalah yang terbaik bila dibandingkan dengan alat skrining lain, baik dari sensitivitas, spesifisitas, MSSS, AUC, dan kappa. Skrining SNST juga dapat membedakan proporsi malnutrisi pada kelas perawatan dan kelompok usia yang berbeda. Selain itu, dibandingkan dengan parameter penilaian status gizi (IMT, LLA, dan Hb), SNST dapat menunjukkan hasil yang berbeda secara signifikan dengan membedakan antara kelompok berisiko dan tidak berisiko malnutrisi.

Analisis validitas dilakukan terhadap beberapa ukuran validitas, diantaranya Se, Sp, MSSS, dan AUC. Sebuah uji bisa jadi sangat spesifik walaupun tidak sensitif, ataupun sangat sensitif namun tidak spesifik(15). Kedua hal tersebut sangat penting dalam uji diagnostik sehingga tes dikatakan yang terbaik apabila memiliki nilai Se dan Sp yang sama baik. Sebuah systematic review terhadap 32 jenis metode skrining membagi kriteria batas-batas nilai Se dan Sp, yaitu baik (Se dan Sp harus $>80 \%$ ); sedang (Se dan Sp harus di antara 50-80\%); dan tidak baik (Se atau Sp <50\%) (16).
Dengan demikian, pada penelitian ini alat skrining SNST, NRS-2002, dan MST memiliki nilai sensitivitas dan spesifisitas yang baik, sementara MUST memiliki sensitivitas yang baik dengan nilai spesifisitas sedang. Bila nilai sensitivitas dan spesifisitas pada sebuah uji memiliki kedudukan yang sama-sama penting, maka dapat dihitung penjumlahan maksimum antara keduanya (MSSS) ataupun mencari besar area bawah kurva atau AUC pada analisis menggunakan kurva ROC (17). Nilai MSSS paling tinggi adalah SNST sebesar 183,5 dibandingkan dengan metode skrining lain. Sementara itu, AUC dikatakan baik apabila nilainya semakin mendekati 1,0 (15). Adapun klasifikasinya sebagai berikut: $0,9-1,0$ sangat baik; $0,8-0,9$ baik; 0,7 - 0,8 cukup; dan 0,6-0,7 kurang baik. Dengan demikian, metode skrining NRS-2002, MST, MUST memiliki AUC yang baik sementara metode skrining SNST memiliki AUC yang sangat baik.

Berdasarkan perhitungan terhadap ukuran-ukuran validitas yang ada, metode skrining SNST memiliki kemampuan yang lebih baik di antara metode skrining lain yang diuji, dengan nilai sensitivitas sebesar 99\%; spesifisitas 84,5\%; MSSS 183,5\%; dan AUC 0,917. Setelah diketahui bahwa SNST memiliki validitas yang lebih baik dari NRS2002, MST, dan MUST, selanjutnya dilakukan analisis untuk membandingkan kelompok berisiko dan tidak berisiko menurut SNST terhadap kaitannya dengan kelompok umur, diagnosis pasien saat masuk (pada penelitian ini diklasifikasikan berdasarkan bangsal perawatan), dan parameter asesmen gizi yaitu IMT, LLA, dan kadar Hb.

Berdasarkan hasil skrining gizi dengan metode SNST, bangsal bedah memiliki proporsi kelompok berisiko malnutrisi yang lebih kecil dibandingkan tidak berisiko malnutrisi; sementara bangsal $\mathrm{PD}+$ saraf memiliki proporsi kelompok berisiko malnutrisi lebih besar dibandingkan tidak berisiko malnutrisi. Berdasarkan perbandingan proporsi tersebut, dapat diketahui pula bahwa jumlah 
kelompok berisiko malnutrisi di bangsal PD+saraf lebih banyak dibandingkan di bangsal bedah. Hal ini karena pasien di bangsal bedah yang diikutsertakan merupakan pasien bedah umum yang menjalani perawatan perioperatif tanpa dibedakan jenis pembedahannya dan sebagian besar merupakan pasien bedah elektif (dengan penundaan).

Penelitian terhadap 4000 pasien di Brazil juga membuktikan bahwa status gizi pasien dipengaruhi oleh diagnosis penyakitnya, yaitu secara umum lebih sedikit pasien bedah $(39 \%)$ yang mengalami malnutrisi dibandingkan pasien penyakit dalam, infeksi, kanker, dan lainnya (57,2\%). Selain itu, pasien yang mendapatkan pembedahan di bagian organ sensoris, otot, dan rangka cenderung sangat sedikit mengalami malnutrisi dibandingkan pasien bedah digestif atau organ lainnya (18). Namun, pasien yang menjalani pembedahan elektif memiliki risiko malnutrisi yang lebih kecil(19). Pasien di bangsal penyakit dalam dan saraf juga lebih cenderung memiliki komplikasi yang lebih banyak dibandingkan pasien di bangsal bedah. Komplikasi mampu menyebabkan malnutrisi pada pasien karena meningkatkan kebutuhan energi pasien sementara kondisi sakit menyebabkan asupan menurun dan penyerapan zat gizi yang buruk(20).

Berdasarkan hasil skrining gizi dengan metode SNST, proporsi kelompok dewasa muda dan dewasa tua mengalami risiko malnutrisi lebih sedikit dibandingkan yang tidak berisiko malnutrisi. Sementara, kelompok usia lanjut yang berisiko malnutrisi lebih banyak dibandingkan yang tidak berisiko malnutrisi. Hasil analisis menggambarkan pula adanya tren peningkatan kejadian risiko malnutrisi pada pasien dengan kelompok umur yang lebih tua. Risiko malnutrisi juga meningkat pada pasien usia lanjut yang sering ditemukan adanya penyakit degeneratif dengan komplikasi, kehilangan massa lemak dan otot yang berlebihan, dan IMT yang sangat rendah(21).

Akan tetapi, skrining gizi dengan metode SNST pada kelompok umur dewasa tua dan usia lanjut tidak menunjukkan adanya perbedaan proporsi yang bermakna pada kelompok berisiko dan tidak berisiko. Hal ini menjadi keterbatasan kemampuan pengukuran SNST pada usia yang lebih tua, yang mana kemudian dapat dianalisis lebih lanjut bila perlu pada penelitian berikutnya mengenai seberapa besar faktor usia lanjut mempengaruhi hasil skrining SNST.
Lebih lanjut, ditemukan adanya perbedaan rerata LLA, median IMT, dan median kadar Hb yang bermakna pada kelompok pasien berisiko dan tidak berisiko. Median IMT pada kelompok berisiko lebih kecil dibandingkan dengan kelompok tidak berisiko. Demikian juga dengan rerata LLA pada kelompok berisiko lebih kecil dibandingkan dengan kelompok tidak berisiko dengan selisih sebesar $2,86 \mathrm{~cm}$. IMT dapat digunakan untuk menentukan risiko malnutrisi pada kelompok kurus sekaligus risiko penyakit pada kelompok gemuk hingga obes. Namun, pengukuran dengan IMT dapat terganggu apabila pasien mengalami oedema/asites. Dengan demikian, LLA merupakan indikator yang sangat membantu dalam penentuan status malnutrisi pada pasien (22).

Median kadar $\mathrm{Hb}$ pada kelompok berisiko lebih kecil dibandingkan dengan kelompok tidak berisiko. $\mathrm{Hb}$ merupakan faktor biokimia yang sangat dipengaruhi oleh asupan makan. Apabila kadar $\mathrm{Hb}$ rendah, kemungkinan tubuh kekurangan zat gizi dalam jumlah banyak dan dalam waktu yang lama (23). Pada pasien dengan penyakit tertentu seperti Chronic Heart Failure (CHF), $\mathrm{Hb}$ merupakan salah satu prediktor mortalitas pasien. Pasien CHF dengan komplikasi anemia memiliki daya tahan yang lebih buruk dan harapan hidup yang lebih pendek dibandingkan pasien CHF yang tidak anemia (24).

Berdasarkan hasil penelitian ini, dapat diketahui bahwa semua alat skrining gizi dapat digunakan untuk memprediksi malnutrisi pada pasien rawat inap rumah sakit karena memiliki nilai validitas yang baik dan di antara alat skrining yang digunakan, SNST adalah alat skrining terbaik karena nilai validitasnya yang tertinggi di antara alat skrining lain berdasarkan baku emas SGA. Pada penelitian selanjutnya, dapat dilakukan hal serupa, tetapi dengan populasi subjek yang lebih besar dan pada kondisi pasien yang berbeda sehingga dapat diketahui gambaran risiko malnutrisi pasien pada berbagai kondisi serta kemampuan SNST dalam memprediksi malnutrisi.

\section{SIMPULAN}

Nilai validitas alat skrining yang digunakan (NRS 2002, MST, MUST, dan SNST) baik terhadap baku emas 
SGA sehingga keempat alat skrining tersebut dapat digunakan untuk memprediksi malnutrisi pasien. Pada penelitian ini, SNST merupakan alat skrining terbaik karena memiliki nilai validitas (Se, Sp, MSSS, dan AUC) tertinggi dibandingkan alat skrining lain terhadap baku emas SGA. Skrining SNST juga dapat menunjukkan perbedaan nilai dari parameter penilaian status gizi secara signifikan antara dua kelompok, yaitu pasien berisiko malnutrisi memiliki IMT, LLA, dan kadar Hb lebih rendah dibandingkan yang tidak berisiko malnutrisi.

\section{Pernyataan konflik kepentingan}

Tidak ada konflik kepentingan dalam penelitian ini.

\section{RUJUKAN}

1. Correia MITD, Campos ACL. Prevalence of hospital malnutrition in Latin America: the multicenter ELAN study. Nutrition 2003;19(10):823-825.

2. Pirlich M, Schutz T, Norman K, Gastell S, Lübke HJ, Lochs H, et al. The German hospital malnutrition study. Clin Nutr 2006;25:563-572.

3. Burgos R, Sarto B, Ello I, Planas M, Forga M, Salas-Salvadó $\mathrm{J}$, et al. Prevalence of malnutrition and its etiological factors in hospitals. Nutr Hosp 2012;27(2):469-76.

4. Stroud M, Duncan H, Nightingale J. Guideline for enteral feeding in adult hospital patients. Gut 2003;52(VII):112.

5. Kruizenga HM, Seidell JC, de Vet HCW, Wierdsma NJ, van Bokhorst-de van der Schueren MAE. Development and validation of a hospital screening tool for malnutrition: the short nutritional assessment questionnaire (SNAQ). Clin Nutr 2005;24:75-82.

6. Powell-Tuck J, Hennessy EM. A comparison of mid upper arm circumference, body mass index and weight loss as indices of undernutrition in acutely hospitalized patients. Clin Nutr 2003;22(3):307-312.

7. Weekes CE, Elia M, Emery PW. The development, validation and reliability of a nutrition screening tool based on the recommendations of the British Association for Parenteral and Enteral Nutrition (BAPEN). Clin Nutr 2004;23(5):1104-12.

8. Kondrup J, Allison SP, Elia M, Vellas B, Plaut M. ESPEN guidelines for nutrition screening 2002. Clin Nutr 2003;22(4):415-21.

9. Malnutrition Advisory Group. The 'MUST' explanatory booklet: a guide to the malnutrition universal screening tool (MUST) for adults. Worcs: BAPEN Office; 2003.
10. Susetyowati, Hadi H, Hakimi M, Asdie AH. Penembangan metode skrining gizi untuk pasien dewasa rawat inap. Jurnal Gizi Klinik Indonesia 2012;8(4):188-94.

11. Susetyowati, Hadi H, Hakimi M, Asdie AH. Development, validation, and reliability of the simple nutrition screening tool (SNST) for adult hospital patient in Indonesia. Paki J Nut 2014;13(3):157-63.

12. Gibson RS. Principles of nutritional assessment, 2nd edition. New York: Oxford University Press; 2005.

13. Salvino RM, Dechicco RS, Seidner DL. Perioperative nutrition support: who and how - review. Cleve Clin J Med 2004;71(4):345-51.

14. Hurlock EB. Developmental psychology: a life-span approach $\left(29^{\text {th }}\right.$ reprint). New Delhi: Tata McGraw Hill Companies; 2003.

15. Zhu W, Zeng N, Wang N. Sensitivity, specificity, accuracy, associated confidence interval and ROS analysis with practical SAS ${ }^{\circledR}$ implementation. Northeast SAS User Group Proceedings (NESUG) Health Care and Life Sciences. Baltimore, Maryland, 14-17 November 2010.

16. Van Bokhorst-de van der Schueren MAE, Guaitoli PR, Jansma E, de Vet HCW. Nutrition screening tools: does one size fit all? a systematic review of screening tools for the hospital setting. Clin Nutr 2014;33(1):39-58.

17. Zou KH, O’Malley AJ, Mauri L. Receiver-operating characteristic analysis for evaluating diagnostic tests and predictive models. Circulation 2007;115:654-7.

18. Waitzberg DL, Caiaffa WT, Correia, MITD. Hospital malnutrition: The Brazilian National Survey (IBRANUTRI): a study of 4000 patients. Nutrition 2001;17:573-580.

19. Velasco C, Garcia E, Rodriguez V, Frias L, Garriga R, Leon $\mathrm{M}$, et al. Comparison of four nutritional screening tools to detect nutritional risk in hospitalized patients - a multicentre study. Eur J Clin Nutr 2011;65(2):269-74.

20. Barker LA, Gout BISA, Crowe TC. Hospital malnutrition: prevalence, identification and impact on patients and the healthcare system. Int J Environ Res Public Health 2010;8:514-27.

21. Neelemaat F, Meijers J, Kruizenga H, Van Ballegooijen H, Van Bokhorst-de Van der Schueren M. Comparison of five malnutrition screening tools in one hospital inpatient sample. J Clin Nurs 2011;20(15-16):2144-52.

22. Harris D, Haboubi N. Malnutrition screening in the elderly population. J R Soc Med 2005;98(9):411-4.

23. Anjankar SP. Comparison of haemoglobin percentage and nutritional status of post graduate girl students residing in hostel, rented rooms, and home. Bioscience Discovery 2012;3(2):243-50.

24. Sharma R, Francis DP, Pitt B, Poole-Wilson PA, et al. Haemoglobin predicts survival in patients with chronic heart failure: a substudy of the ELITE II trial. Eur Heart J 2004;25(12):1021-8. 